\title{
IMPLIKASI PUTUSAN MAHKAMAH KONSTITUSI NOMOR 69/PUU/XIII/2015 TENTANG PERJANJIAN PERKAWINAN TERHADAP TUJUAN PERKAWINAN
}

\author{
Moh. Faizur Rohman \\ Universitas Islam Negeri Sunan Ampel Surabaya| Jl. A. Yani I I 7 Surabaya \\ faza_veiro@yahoo.co.id
}

\begin{abstract}
: this article discusses changes brought by the ruling of Constitutional Court No. 69/PUU/XIII/20I 5 which reviewed Marriage Law No. I/1974, article 29 on pre nuptial agreement. The article previously stated that such an agreement must be done prior or at the eve of marriage contract was signed. The Constitutional Court decided upon a petition that nuptial agreement may be done prior the marriage or during the marriage. The implication of this reuling by Constitutional Court is the additional legal protection regime that women can have in marriage against misfortunes such as domestic violence and property loss. In doing so, married couples will be focused on the realization of islamic marriage of everlasting, peaceful and happy family.
\end{abstract}

Keywords: MK ruling, nuptial agreement, marriage objective

Abstrak: Salah satu tujuan utama pernikahan adalah terbentuknya keluarga yang bahagia, kekal, penuh kasih sayang di antara suami istri. Namun di luar itu berkemungkinan terjadi permasalahan dalam perkawinan, sehingga butuh diadakan sebuah perjanjian perkawinan. Dalam Undang-Undang Perkawinan Nomor I Tahun 1974 pasal 29 ayat (I) disebutkan bahwa perjanjian perkawinan harus diadakan saat atau sebelum perkawinan dilaksanakan. Hal ini dapat mengganggu konsentrasi pasangan terhadap tujuan utama perkawinan. Ditetapkannya putusan MK Nomor 69/PUU/XIII/20I5, menjadikan frasa "pada waktu atau sebelum perkawinan dilangsungkan" dalam pasal 29 ayat (I) dimaknai dengan "pada waktu, sebelum dilangsungkan atau selama dalam ikatan perkawinan". Jadi, perjanjian perkawinan yang semula harus diadakan sebelum atau saat perkawinan dilangsungkan, sekarang boleh diadakan setelah perkawinan dilangsungkan selama dalam ikatan perkawinan. Implikasi dari hal ini adalah adanya perlindungan hukum lebih, terutama bagi perempuan agar tidak menjadi 
korban kekerasan dalam rumah tangga, menjamin perlindungan terhadap hak milik atau hak guna bangunan suatu harta, pasangan juga lebih fokus terhadap tujuan utama perkawinan yakni membentuk keluarga yang bahagia, kekal, penuh kasih sayang bersama pasangan.

Kata Kunci: Putusan MK, perjanjian perkawinan, tujuan perkawinan.

\section{Pendahuluan}

Manusia sebagai makhluk hidup yang menyandang predikat zoon politicon selalu membutuhkan orang lain dalam memenuhi kebutuhan hidupnya. Setiap individu manusia mempunyai naluri kebutuhan yang melekat dalam diri mereka di mana kebutuhan itu harus dipenuhi untuk menjamin keberlangsungan hidupnya, baik itu kebutuhan jasmani maupun rohani. Salah satu naluri rohaniyah yang butuh untuk dipenuhi adalah kebutuhan biologis. Setiap individu butuh untuk menyalurkan kebutuhan itu dalam rangka melangsungkan keturunan. Agar tidak terjadi kekacauan dalam rangka pemenuhan tersebut, maka perlu diatur dalam sebuah peraturan dan norma baik dalam ruang lingkup adat, agama ataupun negara. Hal tersebut bertujuan agar dalam proses pemenuhan kebutuhan biologis dapat disalurkan dengan benar sesuai dengan aturan yang ada.

Dalam rangka pemenuhan naluri tersebut, diadakan sebuah sistem yang disebut perkawinan. Dengan perkawinan sebagai bentuk aturan dalam pemenuhan kebutuhan biologis akan menjamin ketertiban dalam bermasyarakat. Perkawinan merupakan salah satu kebutuhan mendasar dalam rangka meneruskan proses keturunan. Agar proses melanjutkan keturunan itu dianggap sah, maka perlu dibentuk sebuah peraturan pokok yang mengatur khusus mengenai masalah perkawinan.

Pengaturan perkawinan sudah ada semenjak masyarakat tradisional dengan mempertahankan tradisi adat dan terus berkembang semakin maju mengikuti perkembangan zaman. Hal ini dikarenakan setiap masyarakat memiliki pola pikir yang beragam yang tertuang dalam suatu peraturan dan adat yang bisa jadi menyebabkan perbedaan dengan masyarakat adat lainnya. 
Oleh karena itu, terjadilah perbedaan cara maupun prosesi dalam menjalankan sebuah proses perkawinan di masyarakat adat sesuai dengan aturan adat yang berlaku. Peraturan mengenai perkawinan di Indonesia sudah ada semenjak zaman kerajaan hingga zaman Kolonial Belanda bahkan sampai Indonesia merdeka.

Dasar hukum yang dipakai masyarakat Indonesia sebelum masa kemerdekaan hingga setelah kemerdekaan sebelum tahun 1974 masih menggunakan peraturan turunan dari Belanda. Di mana hukum yang mengatur tentang perkawinan diklasifikasikan berdasarkan golongan penduduk. Bagi golongan penduduk timur asing Cina, penduduk Eropa ataupun WNI keturunan Cina dan Eropa berlaku ketentuan-ketentuan Kitab Undang-Undang Hukum Perdata (KUHPer). Bagi penduduk Timur Asing lainnya beserta WNI keturunannya berlaku ketentuan hukum adat mereka. Sedangkan bagi penduduk Indonesia asli digolongkan dalam 3 kelompok; 1) Bagi penduduk Indonesia asli yang beragama Islam berlaku atas hukum Islam yang telah diterima oleh hukum adat. 2) Bagi penduduk Indonesia asli yang beragama Kristen berlaku hukum Ordinansi Perkawinan Indonesia Kristen (Huwelijk Ordanantie Christen Indonesia), 3) Bagi penduduk Indonesia selain keduanya berlaku hukum perkawinan adat masing-masing.

Dikarenakan begitu beragamnya aturan-aturan terkait dengan perkawinan di Indonesia akhirnya mendorong pemerintah untuk melakukan sebuah unifikasi hukum dalam bidang perkawinan yang berlaku bagi seluruh masyarakat Indonesia hingga akhirnya terbentuklah sebuah Undang-Undang Nomor 1 Tahun 1974 tentang Perkawinan. Dengan terbentuknya Undang-Undang Perkawinan (UUP) Nomor 1 Tahun 1974 diharapkan mampu mengakomodasi kebutuhan masyarakat terkait sebuah aturan pernikahan bagi seluruh masyarakat di Indonesia yang mempunyai legalitas formal dalam sebuah peraturan perundang-undangan.

Perkawinan merupakan kodrat alamiah khususnya bagi kalangan umat manusia dalam melanjutkan keturunan. Dalam upaya menjalankan perkawinan, setiap individu menginginkan 
sebuah perkawinan yang penuh dengan kebahagiaan. Setiap orang bercita-cita membentuk keluarga yang bahagia sehingga menimbulkan suatu kehidupan yang penuh dengan ketentraman dan kedamaian. Hal ini sesuai dengan tujuan perkawinan yang telah disebutkan dalam Pasal 1 UUP No. 1 Tahun 1974 yaitu membentuk keluarga atau rumah tangga yang bahagia dan kekal berdasarkan Ketuhanan Yang Maha Esa. Akan tetapi tidak semua individu bisa melewati terjadinya sebuah perkawinan sesuai dengan yang telah diharapkan. Besar kemungkinan di tengah perjalanan terjadi goncangan terhadap mahligai rumah tangga yang bisa berujung kepada perceraian. Masalah muncul ketika terjadi perceraian, masing-masing pihak akan mempertahankan harta masing-masing yang dianggapnya adalah hasil jerih payahnya selama ini.

Contoh lain dari masalah di atas, jika seorang warga negara Indonesia menikah dengan warga negara asing, menurut UndangUndang Nomor 1 Tahun 1974 menyebutkan "jika telah terjadi perkawinan, maka harta yang diperoleh selama perkawinan adalah merupakan harta bersama". Oleh karena Undang-Undang Nomor 9 Tahun 1960 melarang status kepemilikan hak milik dan hak guna bangunan oleh warga negara asing, maka untuk menyikapi semua hal di atas butuh untuk diadakan sebuah perjanjian perkawinan. Perjanjian dalam konteks tersebut sebagai antisipasi jika terjadi perceraian guna menjamin hak masing-masing pihak terutama status harta. Perjanjian perkawinan akan menjamin hak warga negara Indonesia yang menikah dengan orang asing untuk bisa memiliki aset hak milik atau hak guna bangunan di Indonesia yang telah disepakati dalam perjanjian perkawinan.

Klausul perjanjian perkawinan yang diatur dalam undangundang tidak memberi ruang terhadap perjanjian perkawinan yang dilakukan setelah perkawinan berlangsung. Hal ini karena dalam undang-undang disebutkan bahwa perjanjian perkawinan harus dilakukan pada waktu, bahkan sebelum perkawinan dilangsungkan. Maka masyarakat yang lupa tidak melakukan 
perjanjian sebelum perkawinan atau karena ketidak-tahuan akan adanya perjanjian perkawinan dalam undang-undang, tidak bisa mengajukan perjanjian perkawinan setelah berlangsungnya perkawinan. Maka dengan berat hati hak-hak masyarakat untuk dapat memiliki hak milik dan hak guna bangunan tidak akan bisa terwujud dengan adanya aturan tersebut. Padahal dalam Pasal $28 \mathrm{H}$ ayat (4) UUD 1945 disebutkan bahwa setiap orang berhak mempunyai hak milik pribadi. Hak untuk memiliki sesuatu dengan sah merupakan hak konstitusional yang dijamin dalam UUD 1945.

Melalui proses judicial review terhadap pasal-pasal yang dianggap bertentangan dengan UUD 1945 karena melanggar Hak Asasi Manusia, diharapkan akan menjadi jalan keluar bagi suami istri yang sebelumnya tidak melakukan perjanjian perkawinan. Akhirnya pada 27 Oktober 2015 keluar Putusan Mahkamah Konstitusi yang berkaitan dengan hal tersebut dengan nomor registrasi 69/PUU/XIII/2015.

Berdasarkan hal di atas, maka perlu dikaji lebih dalam bagaimana prosedur perjanjian perkawinan terutama terkait hak milik yang sebelumnya belum diadakan perjanjian pra perkawinan.

\section{Konsep Perkawinan dalam Hukum Adat dan Hukum Islam}

Perkawinan merupakan sebuah prosesi yang harus ditempuh untuk menyatukan dua insan manusia laki-laki dan perempuan sebagai suami istri menjadi satu ikatan sosial ataupun sebuah ikatan hukum yang berakibat adanya hak dan kewajiban antar laki-laki dan perempuan tersebut. Dalam ranah hukum adat, sebuah perkawinan merupakan salah satu upaya bukan hanya menyatukan dua insan laki-laki dan perempuan saja dengan maksud mendapat keturunan dan membangun serta membina kehidupan keluarga rumah tangga, akan tetapi lebih dari itu, yakni menyatukan dua kerabat besar. Terjadinya perkawinan berarti juga berlakunya ikatan kekerabatan untuk dapat saling membantu dan menunjang hubungan kekerabatan yang rukun dan damai. ${ }^{1}$

' Hilman Hadikusuma, Hukum Perkawinan Adat, (Bandung: PT Citra Aditya Bakti, 1995), 70.

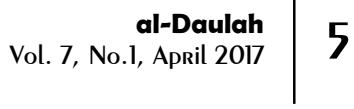


Dalam hukum Islam, perkawinan disebut juga dengan pernikahan merupakan sebuah akad (perjanjian) yang mengandung ketentuan hukum kebolehan melakukan hubungan seksual dengan menggunakan lafal tertentu ${ }^{2}$. Pengertian tersebut hanya menunjukkan kepada hubungan seksual yang asalnya tidak diperbolehkan karena sebab adanya akad dalam suatu perkawinan menjadikan hubungan seksual tersebut diperbolehkan. Dalam bukunya Rahmat Hakim terdapat suatu keterangan bahwa "Nikah adalah suatu akad yang menyebabkan kebolehan bergaul antara seorang laki-laki dengan seorang wanita dan saling tolong menolong di antara keduanya serta menentukan batas hak dan kewajiban di antara keduanya". ${ }^{3}$ Perkawinan tidak saja berakibat kebolehan atas hubungan kelamin bagi laki-laki dan perempuan saja, akan tetapi ada unsur sikap saling tolong menolong antara keduanya sehingga berimplikasi terhadap hak dan kewajiban masing-masing dari pasangan suami istri.

Dalam Undang-Undang Nomor 1 Tahun 1974 tentang Perkawinan menyebutkan bahwa perkawinan merupakan ikatan lahir batin antara seorang pria dan seorang wanita sebagai suami istri dengan tujuan membentuk keluarga atau rumah tangga yang bahagia dan kekal berdasarkan Ketuhanan Yang Maha Esa. ${ }^{4}$ Karena berdasarkan Ketuhanan Yang Maha Esa, maka undang-undang tersebut lebih menitikberatkan kepada perkawinan berdasarkan agama atau kepercayaan masing-masing.

Perkawinan mempunyai beberapa hikmah di antaranya adalah; (1) menyambung silaturrahmi. ${ }^{5}$ Dengan adanya perkawinan kelangsungan manusia terjaga, karena dengan pernikahan maka banyaklah keturunan yang dihasilkan. (2) memalingkan pandangan liar. ${ }^{6}$ Sangat wajar bagi setiap individu

\footnotetext{
${ }^{2}$ Abdul Rahman Ghozali, Figh Munakahat, (Jakarta: Kencana Prenadamedia Group, 2014), 8.

${ }^{3}$ Rahmat Hakim, Hukum Perkawinan Islam (untuk IAIN, STAIN, PTAIS), (Bandung: CV Pustaka Setia, 2000), 13.

${ }^{4}$ Pasal I Undang-Undang Nomor I Tahun 1974 tentang Perkawinan.

${ }^{5}$ Rahmat Hakim, Hukum Perkawinan Islam, 27.

${ }^{6} \mathrm{lbid}$.
} 
utamanya seorang pemuda dalam melihat lawan jenisnya akan memunculkan khayalan-khayalan sesuai dengan nafsunya yang sedang bergejolak. Untuk itu agar pandangan seorang manusia bisa semakin terjaga diperlukan sebuah upaya untuk meredamnya, salah satunya melalui perkawinan. (3) menghindari diri dari perzinaan. ${ }^{7}$ Perzinaan banyak bermula dari sebuah pandangan yang liar. Jika pandangan ini tidak bisa disalurkan dengan baik, dikhawatirkan dapat menggiring manusia ke arah jalan yang sesat. (4) menjaga kemurnian nasab. ${ }^{8}$ Dengan perkawinan yang sah maka keturunan yang dihasilkan akan dapat dikatakan sah pula. Menjaga kemurnian nasab akan keturunan dalam hukum Islam adalah sesuatu yang krusial.

\section{Tujuan Perkawinan}

Setiap perbuatan pasti memiliki tujuan, begitu pula dengan perkawinan. Perkawinan tidak sekedar legalitas dalam hubungan badan suami istri tetapi ada beberapa tujuan dengan diadakannya sebuah perkawinan, di antaranya adalah;

(1) untuk mendapatkan keturunan yang sah guna melanjutkan generasi yang akan datang. ${ }^{9}$ Ini adalah salah satu tujuan utama perkawinan. Untuk mendapatkan keturunan yang sah harus melalui perkawinan yang sah juga.

(2) untuk mendapatkan keluarga bahagia yang penuh ketenangan hidup dan rasa kasih sayang ${ }^{10}$ atau yang disebut dengan keluarga yang sakinah, mawaddah, dan rahmah. Bangsa yang terdiri atas kumpulan keluarga yang harmonis dan kokoh, maka kokoh pulalah bangsa tersebut. Sebaliknya, apabila keluarga sebagai fondasi suatu bangsa itu lemah, lemahlah bangsa tersebut. ${ }^{11}$ Dalam komentarnya, Amir Syarifuddin menjabarkan bahwa dalam penyaluran nafsu syahwat untuk menjamin

\footnotetext{
7 lbid., 28.

${ }^{8}$ lbid., 30

${ }_{9}^{9}$ Amir Syarifuddin, Hukum Perkawinan Islam di Indonesia, (Jakarta: Kencana Prenada Media Group, 2009), 46.

10 lbid., 47.

" Rahmat Hakim, Hukum Perkawinan Islam, 18.
} 
kelangsungan hidup umat manusia bisa saja melalui jalur luar pernikahan. Akan tetapi hal tersebut tidak akan bisa menghasilkan ketenangan dalam hidup bersama suami istri dengan penuh rasa kasih sayang.

(3) sebagai penyaluran syahwat secara sah dan penumpahan kasih sayang berdasarkan tanggung jawab. ${ }^{12}$ Telah banyak diketahui bahwa setiap manusia mempunyai nafsu sahwat yang perlu untuk disalurkan dengan baik, maka perkawinan merupakan satu-satunya cara dalam penyaluran biologis secara sah. Jika syahwat telah tersalurkan dengan baik, maka hal ini bisa memelihara diri dari kerusakan yang diakibatkan oleh nafsu syahwat.

Dalam pasal 1 UU No. 1/1974 disebutkan bahwa "Perkawinan adalah ikatan lahir batin antara seorang pria dan seorang wanita sebagai suami istri dengan tujuan membentuk keluarga atau rumah tangga yang bahagia dan kekal berdasarkan Ketuhanan Yang Maha Esa". ${ }^{13}$ Menurut pasal 1 UU 1/1974 tersebut, tujuan perkawinan lebih kepada hubungan harmonis antara suami istri, lebih kepada membentuk keluarga atau rumah tangga yang bahagia dan kekal berdasarkan atas ketakwaan kepada agama yang dianutnya.

Dari beberapa uraian di atas, tujuan tertinggi sebuah perkawinan adalah memelihara generasi, memelihara gen manusia, dan masing-masing suami istri mendapatkan ketenangan jiwa karena kecintaan dan kasih sayangnya dapat disalurkan dengan baik. $^{14}$

\section{Perjanjian Perkawinan dalam KUHPer, UU dan KHI}

Perjanjian perkawinan berbeda dengan syarat perkawinan. Perjanjian merupakan sebuah istilah yang menunjukkan adanya kesepakatan antar dua pihak atau lebih. Dalam istilah fikih klasik tidak ditemukan secara khusus dan terperinci terkait dengan bab

\footnotetext{
${ }^{12}$ Abdul Rahman Ghozali, Figh Munakahat, 27.

13 Pasal I Undang-Undang No. I Tahun 1974 Tentang Perkawinan.

${ }^{14}$ Abdul Majid Khon, Fiqih Munakahat, (terj. Al-Usrah wa ahkâmuhâ, Abdul Aziz Muhammad Azzam, Abdul Wahhab Sayyed Hawwas), (Jakarta: Amzah, 20I I), 36.
} 
perjanjian perkawinan, tetapi yang ada adalah rukun dan syarat dalam perkawinan. Perjanjian perkawinan termasuk istilah modern yang muncul dalam aturan-aturan perkawinan di Indonesia. Perjanjian perkawinan bukan merupakan sebuah syarat-syarat yang diucapkan dalam prosesi akad, akan tetapi perjanjian yang dimaksud di sini dilakukan di luar prosesi akad perkawinan meskipun dalam suasana atau majelis yang sama. ${ }^{15}$

Menurut Abdul Rahman Ghozali, Perjanjian perkawinan yaitu persetujuan yang dibuat oleh kedua calon mempelai pada waktu atau sebelum perkawinan dilangsungkan, dan masing-masing berjanji akan mentaati apa yang tersebut dalam persetujuan itu, yang disahkan oleh pegawai pencatat nikah. ${ }^{16}$ Dari pengertian tersebut diketahui bahwa penekanan perjanjian perkawinan harus dibuat oleh kedua calon, hal ini menunjukkan bahwa perjanjian perkawinan dibuat sebelum perkawinan dilangsungkan, atau maksimal saat perkawinan itu dilangsungkan. R. Subekti memberikan pengertian bahwa perjanjian perkawinan adalah suatu perjanjian mengenai harta benda suami istri selama perkawinan mereka yang menyimpang dari asas atau pola yang ditetapkan oleh undang-undang. ${ }^{17}$

Perjanjian dalam perkawinan terpisah dari akad nikah, maka tidak ada kaitan hukum antara akad nikah yang dilaksanakan secara sah dengan pelaksanaan syarat yang ditentukan dalam perjanjian. Oleh karena itu, tidak terpenuhinya perjanjian tidak menyebabkan batalnya nikah yang sudah sah. Akan tetapi pihakpihak yang dirugikan atas tidak terpenuhinya syarat dalam perjanjian perkawinan tersebut berhak untuk mengajukan pembatalan perkawinan. ${ }^{18}$

\footnotetext{
${ }^{15}$ Amir Syarifuddin, Hukum Perkawinan Islam di Indonesia, 146.

${ }^{16}$ Abdul Rahman Ghozali, Fiqh Munakahat, 119.

17 R. Subekti, Pokok-Pokok Hukum Perdata, (Jakarta: Intermsa, 1994), 9 dalam Annisa Istrianti \& Erwan Priambada, "Akibat Hukum Perjanjian Perkawinan yang Dibuat Setelah Perkawinan Berlangsung", Privat Law Vol. III No. 2 Juli-Desember 20I5, (Surakarta, 20I5), 85.

${ }^{18}$ Amir Syarifuddin, Hukum Perkawinan Islam di Indonesia, I 46.
} 
Pada umumnya suatu perjanjian perkawinan dibuat dengan alasan; (1) Apabila terdapat sejumlah kekayaan yang lebih besar pada salah satu pihak dari pada pihak lain; (2) Kedua belah pihak masing-masing membawa masukan yang besar; (3) Kedua belah pihak memiliki usaha sendiri, sehingga apabila salah satu mengalami bangkrut maka pihak yang lain tidak tersangkut; (4) Atas utang-utang yang mereka buat sebelum kawin, masingmasing akan bertanggung gugat sendiri-sendiri. ${ }^{19}$

Dalam Islam, perjanjian perkawinan berhukum mubah atau boleh untuk dilakukan selama perjanjian perkawinan yang dibuat itu tidak bertentangan dengan syariat Islam atau hakikat perkawinan itu sendiri. ${ }^{20}$ Jika syarat perjanjian yang dibuat bertentangan dengan syariat Islam atau hakikat perkawinan, apapun perjanjian itu maka perjanjian itu tidak sah, akan tetapi akad nikahnya tetap sah. ${ }^{21}$

Jumhur ulama berpendapat bahwa memenuhi syarat yang dinyatakan dalam bentuk perjanjian, hukumnya adalah wajib sebagaimana hukum memenuhi perjanjian lainnya. ${ }^{22}$ Kewajiban memenuhi persyaratan dalam kelangsungan perkawinan tergantung bentuk persyaratan yang ada dalam perjanjian. Berikut adalah bentuk persyaratan dalam perjanjian tersebut:

(1) Syarat yang langsung berkaitan dengan pelaksanaan kewajiban suami istri dalam perkawinan dan merupakan tuntutan dari perkawinan itu sendiri. ${ }^{23}$ Misalkan syarat dalam perjanjian itu terkait dengan suami harus memberi nafkah untuk anak dan istrinya, di mana nafkah sendiri termasuk dalam kewajiban suami. Syarat yang ada dalam perjanjian ini menurut jumhur ulama' adalah wajib dilaksanakan. Akan tetapi jika syarat ini

\footnotetext{
19 Titik Triwulan Tutik, Hukum Perdata Dalam Sistem Hukum Nasional, (Jakarta: Kencana Prenada Media Grup, 201 I), 121.

${ }^{20}$ Abdul Rahman Ghozali, Fiqh Munakahat, 119.

2l Zakiah Daradjat, IImu Figh, jilid 2, (Yogyakarta: Dana Bhakti Wakaf, 1995), 93 dalam Abdul Rahman Ghozali, Figh Munakahat, 120.

${ }^{22}$ Amir Syarifuddin, Hukum Perkawinan Islam di Indonesia, I 46.

${ }^{23} \mathrm{lbid}, 147$.
} 
tidak dipenuhi, tidak serta merta langsung dapat membatalkan akad perkawinan. Hanya saja ada hak bagi pihak yang dirugikan untuk menuntut pembatalan perkawinan di pengadilan.

(2) Syarat-syarat yang bertentangan dengan hakikat perkawinan, atau yang secara khusus dilarang untuk dilakukan atau memberi mudarat kepada pihak-pihak tertentu. ${ }^{24}$ Misalnya suami istri mempersyaratkan tidak akan beranak, atau suami mempersyaratkan istrinya mencari nafkah dengan tidak halal/melacur. Maka menurut jumhur ulama syarat yang semacam ini tidak wajib untuk dilaksanakan karena bertentangan dengan hakikat perkawinan itu sendiri, bahkan haram hukumnya jika bertentangan dengan norma agama.

(3) Syarat-syarat yang tidak menyalahi tuntutan perkawinan dan tidak ada larangan secara khusus namun tidak ada tuntutan secara syara' untuk dilakukan. ${ }^{25}$ Misalkan dalam perjanjian, mensyaratkan hasil pencarian dalam rumah tangga menjadi milik bersama atau istri mensyaratkan suami tidak memadunya. Menyikapi hal ini ulama berbeda pendapat. Menurut jumhur yang diantaranya ulama Syafi'iyah berpendapat bahwa syarat tersebut tidak boleh dipenuhi, namun tidak membatalkan akad perkawinan. Hal ini dikarenakan syarat yang diajukan (tidak berpoligami) adalah mengharamkan sesuatu yang halal. Akan tetapi berbeda dengan pendapatnya ulama Hanabilah dan Ahmad, bahwa syarat tersebut (tidak berpoligami) wajib dipenuhi. Hal ini telah memenuhi apa yang dikatakan Nabi tentang syarat yang paling layak dipenuhi adalah terkait masalah perkawinan. Di samping itu tidak terdapat larangan Nabi secara khusus terkait hal tersebut. Untuk saat ini, pendapat Imam Ahmad sangat relevan dengan usaha memperkecil terjadinya poligami yang tidak bertanggung jawab saat ini. ${ }^{26}$ 
Berdasarkan pendapat ulama fikih Imam Ahmad dan kalangan Hanabilah tersebut, maka persyaratan yang dimasukkan dalam bentuk perjanjian perkawinan sangat terbuka selama tidak ditemukan secara khusus aturan yang melarang syarat tersebut. ${ }^{27}$ Saat ini telah berkembang perjanjian perkawinan dalam bentuk syarat-syarat mengenai ta'lik talak, ataupun terkait masalah harta yang dihasilkan dalam perkawinan.

Di Indonesia, terdapat 3 (tiga) produk peraturan perundangundangan yang mengatur masalah perjanjian perkawinan, yaitu Kitab Undang-Undang Hukum Perdata, Undang-Undang Nomor 1 Tahun 1974 mengenai Perkawinan, dan Inpres nomor 1 tahun 1974 tentang Kompilasi Hukum Islam. Sejak berlakunya UndangUndang Nomor 1 Tahun 1974 tentang Perkawinan, maka di negara Indonesia telah terjadi unifikasi dalam bidang hukum perkawinan, kecuali sepanjang yang belum/tidak diatur dalam undang-undang tersebut, maka peraturan lama dapat dipergunakan.28

Dalam pasal 139 KUHPer disebutkan bahwa "Para calon suami istri dengan perjanjian kawin dapat menyimpang dari peraturan undang-undang mengenai harta bersama asalkan hal itu tidak bertentangan dengan tata susila yang baik atau dengan tata tertib umum dan diindahkan pula ketentuan-ketentuan berikut." ${ }^{29}$ Dalam redaksinya, perjanjian perkawinan yang disebutkan dalam KUHPer secara eksplisit menunjukkan bahwa perjanjian perkawinan itu dilakukan sebelum terjadinya perkawinan. Hal ini karena redaksi yang disebutkan dalam KUHPer adalah para calon suami istri.

Dalam pasal 147 KUHPer disebutkan bahwa "Perjanjian kawin harus dibuat dengan akta notaris sebelum pernikahan berlangsung, dan akan menjadi batal bila tidak dibuat secara demikian. Perjanjian itu akan mulai berlaku pada saat pernikahan dilangsungkan, tidak

\footnotetext{
27 Ibid.

${ }^{28}$ K. Wantjik Saleh, Hukum Perkawinan Indonesia, (Jakarta: Ghalia Indonesia, 1982), 3 dalam Hanafi Arief, "Implementasi Yuridis Perjanjian Kawin dalam Sistem Hukum Positif di Indonesia", Syariah Jurnal Ilmu Hukum, Vol. I 5 Nomor 2 Desember 2015 (Banjarmasin, 20 I 5), 142.

29 Pasal 139 Kitab Undang-undang Hukum Perdata.
}

\begin{tabular}{l|l}
12 & $\begin{array}{l}\text { al-Daulah } \\
\text { Vol. 7. No. 1. April } 2017\end{array}$
\end{tabular} 
boleh ditentukan saat lain untuk itu"30. Dari pasal tersebut dapat diambil kesimpulan bahwa (1) perjanjian harus dibuat dengan akta notaris (2) perjanjian mulai berlaku saat pernikahan dilangsungkan meskipun proses pembuatan perjanjian tersebut sebelum perkawinan dilangsungkan.

Perjanjian yang dibuat dengan akta notaris tersebut baru berlaku efektif antara suami dan istri setelah perkawinan berlangsung. Akan tetapi perjanjian itu baru berlaku efektif terhadap pihak ketiga apabila perjanjian tersebut telah didaftarkan Kepaniteraan Pengadilan Negeri. ${ }^{31}$ Sekilas antara UU No.1/1974 dengan KUHPerdata pasal 152 agak berbeda, tetapi apabila diteliti lebih jauh maka prinsipnya sama, dalam Pasal 13 PP No. 9 Tahun 1975 menentukan bahwa helai kedua dari akta perkawinan disimpan pada Panitera Pengadilan dalam Wilayah kantor pencatatan perkawinan itu berada. ${ }^{32}$ Dalam pasal 13 PP No. 9/1975 disebutkan "akta perkawinan dibuat dalam rangkap 2 (dua), helai pertama disimpan oleh Pegawai Pencatat, helai kedua disimpan pada Panitera Pengadilan dalam wilayah Kantor pencatatan perkawinan itu berada" 33

Perjanjian perkawinan dalam Undang-Undang Perkawinan bukan hanya mengatur masalah harta benda dan akibat perkawinan saja melainkan juga meliputi hak-hak dan kewajiban yang harus dipenuhi oleh kedua belah pihak sepanjang perjanjian perkawinan itu tidak bertentangan dengan batas-batas hukum, agama dan kesusilaan. ${ }^{34}$

Bentuk-bentuk perjanjian perkawinan yang disebutkan dalam bukunya Abdul Rahman Ghozali adalah (1) Ta'lik Talak, (2)

\footnotetext{
${ }^{30}$ Pasal 147 Kitab Undang-undang Hukum Perdata.

31 Pasal I 52 Kitab Undang-undang Hukum Perdata.

32 Erlando Parsaoran Siburian, "Perjanjian Perkawinan Menurut Undang-Undang Nomor I Tahun 1974 terhadap Harta Warisan dan Kaitannya Dengan Putusan Mahkamah Konstitusi Nomor 46/PUU-VIII/20 I0 tentang Masalah Anak Luar Kawin", Lex Privatum, Vol.III/No.3/Jul-Sep/20I5, 93.

${ }_{33}$ Pasal 13 ayat (I) PP Nomor 9 Tahun 1975.

${ }^{34}$ Fitria Herawati, Perlindungan Hukum Bagi Pihak Ketiga dalam Terjadinya Pembatalan Perjanjian Perkawinan, (Tesis, Universitas Brawijaya Malang), 13.
} 
Perjanjian lain yang tidak bertentangan dengan hukum Islam. ${ }^{35} \mathrm{Hal}$ ini seperti yang dicantumkan dalam Kompilasi Hukum Islam (KHI) dalam Pasal 45 disebutkan; "Kedua calon mempelai dapat mengadakan perjanjian perkawinan dalam bentuk: 1. Ta'lik talak, dan 2. Perjanjian lain yang tidak bertentangan dengan hukum Islam. ${ }^{36}$

Akan tetapi hal ini berbeda dengan perjanjian yang dicantumkan dalam penjelasan Pasal 29 Undang-Undang Nomor 1 Tahun 1974 tentang Perkawinan yang menerangkan bahwa perjanjian ini tidak termasuk perjanjian ta'lik talak. Karena itu tujuan perjanjian perkawinan adalah untuk menyatukan harta bawaan menjadi harta bersama. ${ }^{37}$ Berbeda dengan KHI yang mencantumkan ta'lik talak dalam bentuk perjanjian perkawinan.

Lebih lanjut mengenai perjanjian perkawinan itu diadakan dengan tujuan; (1) Melindungi harta benda masing-masing suami istri secara hukum. (2) Melindungi anggota keluarga dari ancaman kekerasan rumah tangga. ${ }^{38}$ (3) Sebagai alat bukti yang sah (4) Mencegah perbuatan yang tergesa-gesa, oleh karena akibat dari perkawinan itu seumur hidup. ${ }^{39}$

Menurut Kompilasi Hukum Islam mengenai perjanjian perkawinan diatur dalam pasal 45 sampai dengan pasal 52. "perjanjian perkawinan" menurut KHI bukan hanya terbatas pada harta yang didapat selama perkawinan, akan tetapi mencakup harta bawaan masing-masing suami isteri. ${ }^{40}$ Sedangkan yang dimaksud perjanjian perkawinan terhadap harta bersama yaitu perjanjian tertulis yang disahkan oleh pegawai pencatat nikah, perjanjian tersebut dibuat oleh calon suami istri untuk mempersatukan dan

\footnotetext{
${ }^{35}$ Abdul Rahman Ghozali, Fiqh Munakahat, 121.

${ }^{36}$ Pasal 45 Kompilasi Hukum Islam.

${ }^{37}$ Dakwatul Chairah, Hukum Perkawinan Islam di Indonesia, (Surabaya: UIN Sunan Ampel Press, 20|4), 82

38 Pugung Solahudin, Mendapat Hak Asuh Anak dan Harta Bersama di Pengadilan Agama, (Jakarta: Indonesian Legal Center Publishing, 20I I), I8 dalam Inas Sacharissa, Akibat Hukum Perjanjian Perkawinan Terhadap Harta Bersama, (Skripsi--Semarang, 20I5), 22.

${ }^{39}$ Inas Sacharissa, Akibat Hukum Perjanjian Perkawinan Terhadap Harta Bersama, 22

${ }^{40}$ lbid., 21
} 
memisahkan harta kekayaan pribadi masing-masing selama perkawinan berlangsung, tergantung dari apa yang disepakati oleh para pihak yang melakukan perjanjian. Isi perjanjian tersebut berlaku pula bagi pihak ketiga sejauh pihak ketiga tersangkut. ${ }^{41}$ Sebagai konsekuensi sebuah perjanjian maka bila salah satu pihak melakukan pelanggaran (inkar janji) dapat dilakukan gugatan baik gugatan cerai atau ganti rugi. ${ }^{42}$

Dalam KHI disebutkan, Pasal 46 KHI;

1. Isi ta'lik talak tidak boleh bertentangan dengan hukum Islam.

2. Apabila keadaan yang disyaratkan dalam talik talak betulbetul terjadi kemudian, tidak dengan sendirinya talak jatuh. Supaya talak sungguh-sungguh jatuh, istri harus mengajukan persoalannya ke Pengadilan Agama.

3. Perjanjian ta'lik talak bukan suatu perjanjian yang wajib diadakan pada setiap perkawinan, akan tetapi sekali ta'lik talak sudah diperjanjikan, tidak dapat dicabut kembali.

Pasal 47 KHI;

1. Pada waktu atau sebelum perkawinan dilangsungkan kedua calon mempelai dapat membuat perjanjian tertulis yang disahkan Pegawai Pencatat Nikah mengenai kedudukan harta dalam perkawinan.

2. Perjanjian tersebut pada ayat (1) dapat meliputi percampuran harta pribadi dan pemisahan harta pencaharian masingmasing sepanjang hal itu tidak bertentangan dengan hukum Islam.

3. Di samping ketentuan dalam ayat (1) dan (2) di atas, boleh juga isi perjanjian itu menetapkan kewenangan masing-masing untuk mengadakan ikatan hipotek atas harta pribadi dan harta bersama atau harta syarikat.

Berdasarkan pasal 29 UU No. 1 tahun 1974 memuat beberapa ketentuan dalam pembuatan perjanjian perkawinan; (1) Perjanjian

${ }^{4}$ HR. Damanhuri, Segi-Segi Hukum Perjanjian Perkawinan Harta Bersama, (Bandung: Mandar Maju, 2007), 12 dalam Inas Sacharissa, Akibat Hukum Perjanjian Perkawinan Terhadap Harta Bersama, 22 ${ }^{42}$ Hanafi Arief, Implementasi Yuridis Perjanjian Kawin dalam Sistem Hukum Positiffi Indonesia, 147 
perkawinan dibuat pada waktu atau sebelum perkawinan dilangsungkan. (2) Mengajukan perjanjian tertulis yang disahkan oleh pegawai pencatat perkawinan. (3) Tidak melanggar batas-batas hukum, agama dan kesusilaan. (4) Perjanjian tersebut berlaku sejak perkawinan dilangsungkan. (5) Perjanjian tersebut tidak dapat diubah kecuali ada persetujuan dari kedua belah pihak dengan catatan tidak merugikan pihak ketiga. ${ }^{43}$ (6) Perjanjian dimuat dalam akta perkawinan. ${ }^{44}$

Sejak mulai perkawinan terjadi, adanya suatu percampuran antara kekayaan suami dan kekayaan isteri (algehele gemeenschap van goederen) jika tidak diadakan perjanjian apa-apa. Keadaan yang demikian itu berlangsung seterusnya dan tak dapat diubah lagi selama perkawinan. Jika orang ingin menyimpang dari peraturan umum itu, ia harus meletakan keinginannya itu dalam suatu "perjanjian perkawinan" (huwelijksvoorwaarden). Perjanjian yang demikian ini, harus diadakan sebelum pernikahan dilaksanakan dan harus diletakan dalam suatu akta notaris. Juga keadaan sebagaimana diletakan dalam perjanjian itu, tak dapat diubah selama perkawinan. Undang-undang menghendaki supaya keadaan kekayaan dalam suatu perkawinan itu tetap. Ini demi untuk melindungi kepentingan-kepentingan pihak ketiga. ${ }^{45}$

Oleh karena itu perjanjian perkawinan sebaiknya tidak dibuat di bawah tangan tetapi harus disahkan oleh notaris, kemudian harus dicatatkan pula dalam lembaga pencatatan perkawinan. Artinya pada saat perkawinan dilangsungkan perjanjian perkawinan juga harus disahkan pula oleh pegawai pencatat perkawinan Kantor Catatan Sipil. ${ }^{46}$

\footnotetext{
${ }^{43}$ Pasal 29 Undang-Undang No. I Tahun 1974 tentang Perkawinan

${ }^{44}$ Pasal I2H PP No. 9 Tahun 1975

45 Subekti, Pokok-pokok Hukum Perdata, (Bandung: Internusa, 1982), 31 dalam Yoyon M. Darusman, "Kajian Yuridis Pengujian Undang-undang Pasal 29 Ayat (I), Ayat (3), Ayat (4), Pasal 35 Ayat (I) UU No. I/I 974 Tentang Perkawinan (studi pada putusan MK No. 69/PUU-XIII/20 I5)", Prosiding Seminar Ilmiah Nasional, (Pascasarjana Universitas Pamulang, Tangerang, 2016)

${ }^{46}$ Fitria Herawati, Perlindungan Hukum Bagi Pihak Ketiga,. 17
} 
Perjanjian perkawinan dilakukan sebelum diadakan perkawinan dan harus dituangkan dalam akta notaris. Dalam perjanjian perkawinan dapat diperjanjikan, bahwa meskipun akan berlaku percampuran harta kekayaan antara suami dan istri, beberapa benda tertentu tidak akan masuk percampuran itu. Juga seorang yang memberikan suatu benda kepada salah satu pihak dapat memperjanjikan bahwa benda tersebut tidak akan jatuh di dalam percampuran kekayaan. ${ }^{47}$

Maksud UU dengan memberikan ruang kepada para pihak yang mengikatkan diri dalam suatu perjanjian perkawinan adalah untuk memberikan kepastian hukum kepada para pihak agar dapat memisahkan mana yang termasuk ke dalam harta bawaan dan mana yang termasuk ke dalam harta campuran. Harta bawaan adalah harta benda yang sudah dimiliki oleh masing-masing pihak sebelum perkawinan dapat dalam bentuk harta yang diperoleh melalui hibah, warisan dan lainnya, sedangkan harta campuran adalah harta yang diperoleh secara bersama-sama selama dalam perkawinan. Karena pada dasarnya harta benda akan menjadi masalah pada saat terjadi berakhirnya perkawinan disebabkan adanya perceraian. Dalam rangka adanya kepastian hukum yang berkeadilan, makanya UU memberikan ruang dengan diberikannya ketentuan hukum yang mengatur tentang perjanjian. ${ }^{48}$

\section{Substansi Putusan MK 69/PUU/XIII/2015}

Putusan Mahkamah Konstitusi Nomor 69/PUU/XIII/2015 yang disahkan dalam sidang Pleno Mahkamah Kontitusi pada hari Kamis tanggal 27 Oktober 2016 sebenarnya menitikberatkan kepada hak milik dan hak guna bangunan seseorang. Akan tetapi hal ini juga menyangkut terkait dengan masalah perkawinan terutama perkawinan campuran antara WNI dengan warga asing.

Dalam pengujian yang diajukan oleh pemohon adalah Pasal 21 ayat (1), ayat (3), Pasal 36 ayat (1) UUPA Nomor 5/1960 dan khusus

47 Subekti, Pokok-pokok Hukum Perdata, 32.

48 lbid. 
tekait masalah perkawinan adalah pasal 29 ayat (1) dan pasal 35 ayat (1) Undang-Undang Perkawinan yang dianggap menghilangkan hak pemohon untuk dapat memiliki hak milik dan hak guna bangunan terhadap suatu properti.

Kasus ini bermula ketika Pemohon atas nama Ny. Ikke Farida sebagai WNI yang menikah dengan laki-laki berkewarganegaraan Jepang pada tanggal 22 Agustus 1995 di KUA Kec. Makasar Kotamadya Jakarta Timur dan telah dicatatkan pada Kantor catatan sipil Provinsi DKI Jakarta tertanggal 24 Mei 1999 tidak memiliki perjanjian perkawinan pisah harta dan tidak pernah melepaskan kewarganegaraannya dan tetap memilih kewarganegaraan Indonesia serta tinggal di Indonesia. Pada tanggal 26 Mei 2012, pemohon (WNI) berhasil membeli 1 (satu) unit Rusun, akan tetapi Rusun yang telah dibayar lunas oleh pemohon tersebut tidak kunjung diserahkan kepada pemohon. Bahkan oleh pengembang kemudian perjanjian pembelian dibatalkan secara sepihak dengan dalih suami pemohon adalah warga Negara Asing dan pemohon tidak memiliki perjanjian perkawinan.

Perlu diketahui bahwa jika Ny. Ikke Farida disetujui untuk pembelian Rusun tersebut, maka akan melanggar undang-undang yang berlaku yakni pasal 21 ayat 1, 36 ayat 1 UUPA. Karena dalam pasal 35 UUP menyatakan bahwa harta benda yang diperoleh selama perkawinan menjadi harta bersama. Hal ini berarti jika pembelian Rusun itu terjadi dalam suatu ikatan perkawinan tanpa adanya perjanjian perkawinan, maka Rusun tersebut akan menjadi harta bersama/ gono gini suami istri yang bersangkutan dalam arti sebagian Rusun tersebut akan menjadi milik suami dari pemohon yang notabene adalah warga Negara Asing. Sedangkan dalam pasal 21 ayat 1 ataupun pasal 36 ayat 1 UU No.5/1960 menjelaskan bahwa yang dapat mempunyai hak milik atau hak guna bangunan adalah warga Negara Indonesia.

Berbeda jika dalam ikatan perkawinan sebelumnya sudah terdapat suatu perjanjian perkawinan tentang harta gono gini atau yang bersangkutan dengan harta perkawinan lainnya. Sedangkan 
jika disiasati dengan akan dibuatnya perjanjian perkawinan setelah terjadinya pernikahan ini, maka hal itu akan bertentangan dengan pasal 29 ayat 1 UU No. 1/1974 tentang perkawinan yang menyatakan bahwa perjanjian perkawinan hanya dapat dibuat sebelum atau pada waktu (saat akad) perkawinan dilangsungkan. Oleh karena ketentuan pada pasal 29 ayat 1 UUP tersebut, maka pemohon tidak bisa membuat perjanjian setelah terjadi perkawinan.

Hal ini membuat pemohon merasa kecewa terhadap berlakunya undang-undang tersebut yang dianggap telah merampas hak yang telah dijamin dalam Undang-Undang Dasar 1945. Dalam Pasal 28H ayat 4 UUD 1945 menyebutkan bahwa "Setiap orang berhak mempunyai hak milik pribadi dan hak milik tersebut tidak boleh diambil alih secara sewenang-wenang oleh siapa pun". ${ }^{49}$ Pemohon merasa diperlakukan secara diskriminatif saat adanya penolakan pembelian dari pengembang yang kemudian dikuatkan oleh Pengadilan Negeri Jakarta Timur melalui penetapan Nomor 04/CONS/2014/PN.JKT.Tim tertanggal 12 November 2014 yang memerintahkan untuk melakukan penawaran berupa uang akibat batalnya surat pesanan sebagai akibat dari tidak terpenuhinya syarat obyektif dalam Pasal 1320 KUHPerdata dan merupakan pelanggaran Pasal 36 ayat (1) UU No. 5/1960 tentang Peraturan Dasar Pokok-Pokok Agraria.

Pasal-pasal yang telah disebut di atas, Pasal 21 ayat (1), (3) UUPA dan Pasal 29 ayat (1), (3), (4) UU Perkawinan berpotensi merugikan hak konstitusional pemohon karena pasal-pasal tersebut dapat menghilangkan dan merampas hak pemohon untuk mendapatkan hak milik dan hak guna bangunan. Sehingga Pemohon sebagai warga negara Indonesia tidak akan pernah berhak untuk mempunyai HGB seumur hidupnya. Pemohon sangat terdiskriminasi dan dilanggar hak konstitusionalnya. Pemohon sangat menderita dengan diberlakukannya pasal 21 ayat (1), ayat (3)

${ }^{49}$ Pasal $28 \mathrm{H}$ ayat 4 UUD 1945. 
dan pasal 36 ayat (1) UUPA serta pasal 29 ayat (1), ayat (3), ayat (4) dan pasal 35 ayat (1) UU Perkawinan.

Hak konstitusional pemohon dilanggar karena sebagai warga Indonesia, pemohon mempunyai hak-hak konstitional yang sama dengan warga negara Indonesia lainnya sebagaimana yang dijamin dalam Pasal 27 ayat (1), Pasal 28D ayat (1), Pasal 28E ayat (1), Pasal $28 \mathrm{H}$ ayat (1) dan ayat (4) UUD 1945. ${ }^{50}$ Hak konstitusional pemohon di antaranya untuk bertempat tinggal dan mendapat lingkungan hidup yang baik telah dirampas selamanya. Karena setiap orang pasti ingin memiliki/memberikan bekal bagi diri dan anak-anaknya untuk masa depan. Salah satunya dengan membeli tanah dan bangunan, selain sebagai tempat tinggal, tempat berlindung, juga sebagai tabungan/bekal dimasa depan (hari tua). Hal ini juga akan merampas seluruh hak warga Indonesia seluruhnya yang menikah dengan warga negara asing tanpa ada perjanjian perkawinan sebelumnya.

Alasan mengapa sebelumnya tidak diadakan perjanjian sebelum perkawinan bahwa tujuan perkawinan adalah membentuk keluarga yang bahagia kekal berdasarkan Ketuhanan Yang Maha Esa. Adapun dalam hukum Islam tujuan perkawinan adalah membentuk keluarga sakinah, mawaddah, dan rahmah. Hal itu pun menjadi tujuan utama ketika melakukan perkawinan. Sehingga banyak pasangan yang tidak mempermasalahkan terkait harta, apalagi saat perkawinan dilaksanakan para pasangan tidak mengerti hukum dan masih sangat belia dan juga tidak punya harta. Tidak terbersit sedikitpun dalam hati untuk membuat perjanjian kawin sebelum atau pada saat perkawinan dilangsungkan. Lagi pula pada umumnya semua pasangan yang akan menikah tidak memiliki uang yang cukup untuk membeli tanah apalagi rumah,

50 Yoyon M. Darusman, "Kajian Yuridis Pengujian Undang-undang Pasal 29 Ayat ( I), Ayat (3), Ayat (4), Pasal 35 Ayat (I) UU No. I/I 974 Tentang Perkawinan (studi pada putusan MK No. 69/PUUXIII/20I5)", Prosiding Seminar Ilmiah Nasional, (Pascasarjana Universitas Pamulang, Tangerang, 2016). 
sehingga wajar apabila pada tahap tersebut belum sampai berpikir untuk melakukan perjanjian terkait pembelian tanah atau rumah.

Frasa "pada waktu atau sebelum perkawinan dilangsungkan" pada pasal 29 ayat (1), ayat (4) UU Perkawinan ternyata telah mengekang hak kebebasan berkontrak seseorang. Frasa tersebut membatasi kebebasan waktu dua individu untuk melakukan perjanjian. Karena pada akhirnya seseorang tidak dapat melakukan perjanjian perkawinan jika tidak "pada waktu atau sebelum" perkawinan dilangsungkan.

Mahkamah Konstitusi memutuskan bahwa pasal 29 ayat (1) UU Perkawinan Nomor 1/1974 bertentangan dengan UndangUndang Dasar RI 1945 sepanjang tidak dimaknai "Pada waktu, sebelum dilangsungkan atau selama dalam ikatan perkawinan kedua belah pihak atas persetujuan bersama dapat mengajukan perjanjian tertulis yang disahkan oleh pegawai pencatat perkawinan atau notaris, setelah mana isinya berlaku juga terhadap pihak ketiga sepanjang pihak ketiga tersangkut". ${ }^{51}$ Pasal 29 ayat (3) UU Perkawinan tidak mempunyai hukum mengikat sepanjang tidak dimaknai "Perjanjian tersebut mulai berlaku sejak perkawinan dilangsungkan, kecuali ditentukan lain dalam perjanjian perkawinan". 52

Setelah adanya putusan MK Nomor 69/PUU/XIII/2015 menjamin setiap warga negara Indonesia berhak untuk memiliki hak milik dan hak guna bangunan meskipun perjanjian kawin diadakan setelah perkawinan dilangsungkan. Dalam pasal 29 Undang-Undang Perkawinan yang semula membatasi perjanjian perkawinan hanya boleh dilakukan saat atau sebelum perkawinan menjadi boleh dilakukan setelah perkawinan dilangsungkan. Karena pasal 29 ayat 1 tersebut dianggap bertentangan dengan UUD 1945 yang menjamin hak milik pribadi bagi setiap warga Negara.

\footnotetext{
51 Repository Putusan MK Nomor 69/PUU/XIII/20 I 5, I 56.

52 lbid.
} 
Dengan adanya putusan Mahkamah Konstitusi tersebut menjadikan pasal 29 ayat 1 lebih menjamin hak setiap warga negara untuk mendapatkan hak milik atau hak guna bangunan atau bahkan hak lain melalui perjanjian perkawinan, baik perjanjian itu diadakan sebelum, saat atau bahkan setelah perkawinan dilangsungkan. Hal ini menjadi terobosan hukum baru yang berdampak pada masyarakat luas, karena meskipun saat perkawinan berlangsung belum mengadakan perjanjian perkawinan, kemudian dirasa terdapat masalah yang menuntut diadakannya perjanjian perkawinan, maka seketika itu bisa diadakan perjanjian perkawinan dengan persetujuan kedua belah pihak meskipun perkawinan telah lama dilangsungkan.

\section{Implikasi Putusan MK terhadap Tujuan Perkawinan}

Salah satu alasan yang dapat dijadikan landasan dibuatnya perjanjian kawin setelah perkawinan seperti yang telah diungkapkan Hakim Pengadilan Negeri Jakarta Timur adalah: (1) Ketidak tahuan bahwa dalam Undang-Undang Nomor 1 Tahun 1974 ada ketentuan yang mengatur perjanjian perkawinan sebelum/pada waktu perkawinan dilangsungkan. (2) Adanya risiko yang mungkin timbul dari harta besama setelahnya. (3) Lebih berkembangnya sifat individual dalam kehidupan masyarakat yang mempengaruhi pola pikir suami istri melakukan perjanjian perkawinan untuk melindungi harta masing-masing. (4) Adanya keinginan untuk tetap memiliki sertifikat hak milik atas tanah meskipun dia sebagai WNI menikah dengan orang asing. ${ }^{53}$

Dengan membuat perjanjian perkawinan, suami istri mempunyai kesempatan untuk saling terbuka, saling berbagi rasa atas keinginan-keinginan yang hendak disepakati tanpa harus merugikan salah satu pihak, juga hubungan suami istri menjadi aman, karena jika suatu saat hubungan mereka tidak harmonis lagi

${ }^{53}$ Annisa Istrianti \& Erwan Priambada, Akibat Hukum Perjanjian Perkawinan yang Dibuat Setelah Perkawinan Berlangsung, 91

\begin{tabular}{l|l}
22 & $\begin{array}{l}\text { al-Daulah } \\
\text { Vol. 7. No. 1. April } 2017\end{array}$
\end{tabular} 
dan bahkan sampai pada perceraian, maka ada sesuatu yang dapat dijadikan pegangan dan dasar hukum. ${ }^{54}$

Menurut penelitian pustaka yang dilakukan oleh Annisa Istrianty dan Erwan Priambada dalam artikel yang dimuat dalam Jurnal Privat Law berkesimpulan bahwa perjanjian perkawinan yang dilakukan setelah perkawinan berlangsung berakibat bahwa perjanjian tersebut adalah batal demi hukum karena tidak sesuai dengan peraturan perundang-undangan mengenai perjanjian perkawinan. ${ }^{55}$ Batal demi hukum artinya adalah semula dianggap tidak pernah ada dilahirkannya suatu perjanjian dan tidak pernah ada suatu perikatan ${ }^{56}$ atau dalam maqâlah Arab dikenal istilah wujûduh $\hat{u}$ ka 'adamihî (kehadirannya dianggap tidak pernah ada).

Hal ini yang membuat seperti pada kasus yang dialami oleh Ny. Ikke Farida yang berkeinginan memiliki apartemen/rusun dengan status hak milik atau hak guna bangunan, akan tetapi terganjal dengan status perkawinannya yang menikah dengan warga asing, dengan tidak adanya perjanjian perkawinan sebelumnya dimungkinkan juga disebabkan faktor kealpaan, atau bahkan tidak tahu terkait dengan perjanjian yang harus dibuat sebelum/pada waktu perkawinan menurut undang-undang yang berlaku.

Adanya perjanjian perkawinan melahirkan akibat hukum karena perjanjian tersebut dikehendaki oleh para pihak sehingga menimbulkan beberapa akibat diantaranya; (1) Secara hukum para pihak saling terkait dengan diadakannya perjanjian perkawinan dan masing-masing harus melaksanakan kewajiban dan haknya. Para pihak juga harus siap dengan konsekuensi hukum yang timbul akibat pelanggaran terhadap perjanjian tersebut. (2) Secara

\footnotetext{
54 Yulies Tiena Masriani, "Perjanjian Perkawinan dalam Pandangan Hukum Islam", Serat Acitya, Vol. 2 No. 3 November 20 13, (Universitas Tujuhbelas Agustus Semarang, 2013), I3 I

${ }^{55}$ Annisa Istrianti \& Erwan Priambada, "Akibat Hukum Perjanjian Perkawinan yang Dibuat setelah Perkawinan Berlangsung", 92.

${ }^{56}$ Komang Padma Patmala Adi \& Suatra Putrawan, "Akibat Hukum Terhadap Perjanjian Perkawinan Yang Dibuat Setelah Perkawinan Berlangsung", Kertha Semaya Vol. 0 I No. II, November 2013 (Bali, 20।3), 4.
} 
psikologis, perjanjian perkawinan menimbulkan perasaan tidak percaya terhadap pasangan hidupnya. Karena suatu ikatan yang dibatasi oleh perjanjian yang telah dibuat, sehingga akan menimbulkan kecemasan oleh pasangan. Kecemasan ini akan mengakibatkan ketidakbahagiaan dalam menjalani rumah tangga. (3) Secara sosiologis dan budaya, perjanjian perkawinan akan menimbulkan culture shock. Dikarenakan budaya adat masyarakat timur yang tidak mengenal individualisme tentu menolak adanya perjanjian perkawinan yang dianggap hanya mementingkan harta saja. Meskipun tidak selamanya perjanjian perkawinan berorientasi pada harta dalam perkawinan. ${ }^{57}$

Akan tetapi setelah Mahkamah mengeluarkan putusan Nomor 69/PUU/XIII/2015 terkait perjanjian perkawinan yang semula ketika perjanjian itu dilakukan setelah perkawinan dilangsungkan batal demi hukum, menjadikan perjanjian yang dilakukan meskipun setelah berlangsungnya perkawinan tetap berhukum sah menurut hukum karena putusan MK yang bersifat final dan mengikat.

Kelonggaran batas waktu perjanjian perkawinan yang tidak terbatas hanya sebelum atau saat perkawinan memberikan perlindungan secara hukum kepada setiap pasangan yang ingin terhindar dari kemungkinan terburuk saat perkawinan. Meskipun perjanjian perkawinan saat dapat diadakan setelah perkawinan tidak serta merta menafikan tujuan perkawinan yang mengharapkan kehidupan yang bahagia, kekal serta tidak melulu berorientasi kepada pembagian harta.

Perjanjian perkawinan yang tanpa dibatasi waktu akan semakin melindungi setiap pasangan untuk meraih tujuan dalam perkawinan sebagai langkah antisipasi jika dalam meraih tujuan perkawinan tersebut di tengah jalan mengalami sebuah goncangan yang mengancam dirinya sendiri ataupun keluarga setiap pasangan. Dengan adanya putusan tersebut menjadikan setiap pasangan di awal perkawinan fokus terhadap tujuan perkawinan

${ }^{57}$ Yulies Tiena Masriani, Perjanjian Perkawinan dalam Pandangan Hukum Islam, I 46. 
yakni membentuk keluarga yang bahagia kekal, berdasarkan ketuhanan Yang Maha Esa, bisa saling mencurahkan rasa kasih sayang kepada pasangan masing-masing tanpa memikirkan harta dan lain sebagainya, karena di awal perkawinan tidak terbebani dengan perjanjian perkawinan yang bisa diadakan kapan saja sebelum, saat atau setelah perkawinan dilangsungkan yang lebih berorientasi kepada pembagian harta dalam perkawinan.

\section{Penutup}

Perjanjian perkawinan merupakan sebagai salah satu upaya dalam melindungi anggota keluarga dari ancaman kekerasan rumah tangga, juga melindungi harta benda masing-masing suami istri secara hukum. Akan tetapi dalam peraturan yang berlaku di Indonesia utamanya pasal 29 ayat 1 UU Perkawinan No. 1 Tahun 1974 membatasi waktu perjanjian perkawinan yakni saat atau sebelum perkawinan dilangsungkan.

Maka setiap orang yang hendak menikah harus memikirkan terlebih dahulu terhadap perjanjian perkawinan yang bisa diadakan karena faktor ingin melindungi harta benda masing-masing atau melindungi diri atau keluarga dari ancaman kekerasan rumah tangga. Hal ini menyebabkan substansi tujuan perkawinan bukan sebagai prioritas utama karena di awal perkawinan sudah khawatir akan kemungkinan-kemungkinan yang belum terjadi. Memang itu merupakan sebuah antisipasi akan tetapi bisa menyebabkan substansi tujuan perkawinan menjadi sedikit tersisihkan. Dimana mayoritas diadakannya sebuah perjanjian lebih berorientasi kepada harta benda.

Pembaharuan hukum telah dilakukan Mahkamah Konstitusi dengan keluarnya putusan MK Nomor 69/PUU/XIII/2015. Dengan adanya putusan MK tersebut menjadikan batas waktu terhadap diadakannya perjanjian perkawinan semakin luas, tidak hanya sebelum atau saat perkawinan dilangsungkan tetapi bisa juga diadakan setelah perkawinan dilangsungkan. Pada akhirnya pasangan yang hendak menikah tidak perlu lagi memikirkan perjanjian perkawinan karena saat ini bisa diadakan setelah 
perkawinan dilangsungkan. Maka setiap pasangan akan lebih fokus terhadap tujuan utama perkawinan yakni bisa membentuk keluarga yang sakinah, mawaddah, dan rahmah, tanpa memikirkan akan kekhawatiran terhadap harta perkawinan nantinya. Jika nanti di tengah perjalanan dalam mengarungi kehidupan rumah tangga terdapat masalah yang menyangkut harta perkawinan atau yang lainnya bisa langsung saat itu diadakan perjanjian perkawinan dengan persetujuan para pihak, namun hal itu hanya sebagai kemungkinan terburuk dalam sebuah perkawinan. Harapannya semua pasangan suami istri dapat hidup bahagia, dengan penuh rasa kasih sayang, hidup damai bersama pasangannya.

\section{Daftar Pustaka}

Adi, Komang Padma Patmala \& Suatra Putrawan. "Akibat Hukum Terhadap Perjanjian Perkawinan Yang Dibuat Setelah Perkawinan Berlangsung", Kertha Semaya Vol. 01 No. 11, November 2013, Bali, 2013.

Arief, Hanafi. "Implementasi Yuridis Perjanjian Kawin dalam Sistem Hukum Positif di Indonesia". Syariah Jurnal Ilmu Hukum, Vol. 15 Nomor 2 Desember 2015, Banjarmasin, 2015.

Chairah, Dakwatul. Hukum Perkawinan Islam di Indonesia. Surabaya: UIN Sunan Ampel Press, 2014.

Daradjat, Zakiah. Ilmu Figh. jilid 2, Yogyakarta: Dana Bhakti Wakaf, 1995.

Darusman, Yoyon M. “Kajian Yuridis Pengujian Undang-Undang Pasal 29 Ayat (1), Ayat (3), Ayat (4), Pasal 35 Ayat (1) UU No. 1/1974 Tentang Perkawinan (Studi Pada Putusan MK No. 69/PUU-XIII/2015)". Prosiding Seminar Ilmiah Nasional, Tangerang: Pascasarjana Universitas Pamulang, 2016.

Ghozali, Abdul Rahman. Figh Munakahat. Jakarta: Kencana Prenadamedia Group, 2014.

Hadikusuma, Hilman. Hukum Perkawinan Adat. Bandung: PT Citra Aditya Bakti, 1995. 
Hakim, Rahmat. Hukum Perkawinan Islam (untuk IAIN, STAIN, PTAIS). Bandung: CV Pustaka Setia, 2000.

Herawati, Fitria. Perlindungan Hukum Bagi Pihak Ketiga Dalam Terjadinya Pembatalan Perjanjian Perkawinan. Tesis, Universitas Brawijaya, Malang.tt.

Istrianti, Annisa \& Erwan Priambada. "Akibat Hukum Perjanjian Perkawinan yang Dibuat Setelah Perkawinan Berlangsung". Privat Law Vol. III No. 2 Juli-Desember 2015, Surakarta, 2015.

Khon, Abdul Majid. Fiqih Munakahat cet. 2 (terj. Al Usrah wa Ahkamuha. Abdul Aziz Muhammad Azzam, Abdul Wahhab Sayyed Hawwas), Jakarta: Amzah, 2011.

Masriani, Yulies Tiena. "Perjanjian Perkawinan dalam Pandangan Hukum Islam". Serat Acitya Vol. 2 No. 3 November 2013, UNTAG Semarang, 2013.

Sacharissa, Inas. Akibat Hukum Perjanjian Perkawinan Terhadap Harta Bersama. Skripsi. Semarang, 2015.

Siburian, Erlando Parsaoran. "Perjanjian Perkawinan Menurut Undang-Undang Nomor 1 Tahun 1974 Terhadap Harta Warisan dan Kaitannya Dengan Putusan Mahkamah Konstitusi Nomor 46/PUU-VIII/2010 tentang Masalah Anak Luar Kawin". Lex Privatum, Vol.III/No.3/Jul-Sep/2015.

Syarifuddin, Amir. Hukum Perkawinan Islam di Indonesia. Jakarta: Kencana Prenada Media Group, 2009.

Tutik, Titik Triwulan. Hukum Perdata Dalam Sistem Hukum Nasional. Jakarta: Kencana Prenada Media Grup, 2011.

Undang Undang Dasar 1945

Putusan MK Nomor 69/PUU/XIII/2015, 156

Undang-Undang Nomor 1 Tahun 1974 tentang Perkawinan

Kitab Undang-undang Hukum Perdata

Kompilasi Hukum Islam

PP Nomor 9 Tahun 1975 